\title{
MAPK/ERK signal pathway alterations in patients with Langerhans Cell Histiocytosis
}

\author{
Změny v signální dráze MAPK/ERK u pacientů s histiocytózou \\ Langerhansových buněk
}

\author{
Novosad O. ${ }^{1}$, Skrypets T. ${ }^{1}$, Pastushenko Y. ${ }^{1}$, Titorenko I. ${ }^{1}$, Martynchyk A. ${ }^{1}$, Skachkova O. ${ }^{2}$, Inomistova M. ${ }^{2}$, \\ Gorbach A. ${ }^{2}$, Khranovska N. ${ }^{2}$, Kryachok I. ${ }^{1}$ \\ ${ }^{1}$ Oncohematology Department, National Cancer Institute, Kiev, Ukraine \\ 2 Experimental Oncology Department, National Cancer Institute, Kiev, Ukraine
}

\begin{abstract}
Summary
Background: Clinical outcomes of Langerhans cell histiocytosis $(\mathrm{LCH})$ are highly variable. It has been suggested that mitogen-activated protein kinase (MAPK)/extracellular signal-regulated kinases (ERK) signaling pathway might be activated in LCH patients. Materials and Methods: We investigated KRAS, BRAF and NRAS mutations in patients with $L C H$ by qPCR. Results: Eight adult patients with LCH were treated at the National Cancer Institute, Kiev, Ukraine. Five patients received chemo plus radiation therapy and three patients received only chemotherapy, resp. $(\mathrm{p}<0.05)$. All patients received $\mathrm{LCH}-\mathrm{I}$ study protocol, six cycles in average. A BRAF c.1799T > A, p. V600E mutation was detected in $25 \%(2 / 8)$ of cases - 1 patient had an early relapse in 6 months, and 1 patient - stable disease. We did not find any BRAF, KRAS or NRAS mutations in three patients with late relapses (in 15, 24 and 46 months). Notably, KRAS mutations were not revealed in any LCH samples. The NRAS c.182A > G, p. Q61R mutation was found in two cases - one patient had LCH transformed to Hodgkin's lymphoma, one patient had a refractory disease. Time to relapse rate (TTR) in patients with and without BRAF V600E gene mutation was 13 vs. 28 months, resp. $(p<0.05)$. TTR was 31.3 vs. 6.41 months in patients with absence and presence of NRAS mutation, $\mathrm{p}<0.05$. Multivariate analysis showed the presence of NRAS Q61R mutation was associated with poor event-free survival in LCH patients with $\mathrm{HR}$ of $6.1(95 \% \mathrm{Cl}$ $0.2-12.6 ; \mathrm{p}=0.008$ ). Conclusion: BRAF and NRAS mutations in LCH suggest a possibility of the disease being driven by the activation of the MAPK/ERK pathway. These oncogenic mutations provide new opportunities in understanding $\mathrm{LCH}$ pathogenesis and may be a potential target of therapy.
\end{abstract}

Key words

Langerhans cell histiocytosis - mutations - prognostic factors - relapse - survival
The authors declare they have no potential conflicts of interest concerning drugs, products, or services used in the study.

Autoři deklarují, že $v$ souvislosti s předmětem studie nemaji žádné komerční zájmy.

The Editorial Board declares that the manuscript met the ICMJE recommendation for biomedical papers.

Redakční rada potvrzuje, že rukopis práce splnil ICMJE kritéria pro publikace zasílané do biomedicínských časopisů.

Olga Novosad, MD, PhD

Oncohematology Department

National Cancer Institute

Lomonosova str. 33/43

Kiev-03022

Ukraine

e-mail: novosad.o.ua@gmail.com

Submitted/Obdrženo: 29. 6. 2017

Accepted/Přijato: 29. 12. 2017 


\section{Souhrn}

Úvod: Klinické výstupy histiocytózy Langerhansových buněk (Langerhans cell histiocytosis - LCH) jsou vysoce variabilní. Bylo navrženo, že u pacientů s LCH může být aktivována signální dráha proteinkinázy aktivované mitogenem (MAPK)/extracelulární signální regulační kinázy (ERK). Materiál a metody: Vyšetřili jsme mutace KRAS, BRAF a NRAS u pacientů s LCH pomocí metody kvantitativní polymerázové řetězové reakce. Výsledky: Osm dospělých pacientů s LCH bylo léčeno v Národním onkologickém institutu v Kyjevě na Ukrajině. Pět pacientů dostalo chemoterapii plus radiační terapii a tři pacienti dostali pouze chemoterapii $(p<0,05)$. Všichni pacienti dostávali studijní protokol LCH-I, v průměru šest cyklů. BRAF c.1799T> A, mutace V600E byla detekována u $25 \%$ (2/8) prípadů - jeden pacient měl časný relaps po 6 měsících a jeden pacient stabilní onemocnění. $U$ tří pacientů s pozdními relapsy (v 15, 24 a 46 měsících) jsme nenašli mutace BRAF, KRAS ani NRAS. Je zajímavé, že mutace KRAS nebyly odhaleny u žádných vzorků LCH. NRAS c.182A> G, mutace Q61R byla nalezena ve dvou prípadech - jeden pacient měl LCH transformovaný na Hodgkinův lymfom, jeden pacient měl refrakterní onemocnění. Doba relapsu (time to relapse rate - TTR) u pacientů s mutací genu $B R A F$ V600E a bez mutace byla 13 oproti 28 měsícům, resp. $p<0,05$. TTR byl 31,3 oproti 6,41 měsícům u pacientů s absencí a prítomností mutace NRAS, $\mathrm{p}<0,05$. Multivariační analýza ukázala, že přítomnost NRAS Q61R mutace byla spojena se špatným přežíváním bez př́hody u pacientů $s \mathrm{LCH} s \mathrm{HR}$ $6,1$ (95\% Cl 0,2-12,6; $\mathrm{p}=0,008)$. Závěr: Mutace BRAF a NRAS u LCH naznačují možnost, že onemocnění je řízeno aktivací cesty MAPK/ERK. Tyto onkogenní mutace poskytují nové možnosti v porozumění patogenezi LCH a mohou se stát potenciální cílovou terapií.

Klíčová slova

histiocytóza Langerhansových buněk - mutace - prognostické faktory - relaps - přežití

\section{Introduction}

Langerhans cell histiocytosis (LCH) is a rare myeloproliferative disorder of unknown etiopathogenesis. Based on modern research, $\mathrm{LCH}$ is a disease of the immune system with an abnormal immune response, leading to the proliferation of Langerhans cells, eosinophilic infiltration, granuloma formation, fibrosis, osteolytic lesions, etc.

The age-adjusted incidence rate of LCH is $3-5$ cases in children and $1-2$ cases in adults per 1,000,000 per year, with the incidence rate higher in men than in women. The sex ratio $(m: f)$ is $2: 1$.

Clinical symptoms in LCH patients are very different - from isolated bone lesions to multisystem disease, with outcomes ranging from spontaneous remission to progression during therapy. In addition, symptoms of LCH vary depending on the organ or system involved. Rapid progressive forms are often seen in children and usually not observed in adults [1].

Regardless to similarities in histological features between LCH lesions, clinical outcomes are highly variable and range from isolated skin or bone disease to highly aggressive subtypes with life-threatening multisystem lesions, which require intensive chemotherapy.

There are different types of LCH (stratification of $\mathrm{LCH}$ ):

1. multisystem LCH (MS-LCH) - with or without the involvement of "risk organs";
2. single system LCH (SS-LCH) - unifocal or multifocal lesions;

3. single system LCH (SS-LCH) - with "special site" lesions

There are no universal guidelines for the diagnosis and treatment of adult LCH patients. The largest number of patients was analyzed in a retrospective pooled analysis from several national registries [2,3]. In general, physicians should have an option to choose the course of chemotherapy treatment depending on the stratification of $\mathrm{LCH}$ and presence of genetic mutations.

The benign morphology of LCH proliferating cells and their characteristic inflammatory infiltrates suggest that $\mathrm{LCH}$ may be an inflammatory disorder [4]. Dysregulated expression of inflammatory cytokines, such as interleukin-17A, has been reported [5]. However, the pathologic Langerhans cells in LCH are clonal [6]. Although clonality is an important feature of neoplasia, recurrent genomic abnormalities will be required to demonstrate that $\mathrm{LCH}$ is a neoplasm; until now, none of them have been reported [7].

It is known that the mitogen-activated protein kinase (MAPK) pathway is constantly activated in LCH. Mutations of the downstream kinases BRAF and $M A P 2 K 1$ mediate this activation in a subset of $\mathrm{LCH}$ lesions. The most common missense mutation of BRAF (mainly V600E) contributes to the incidence of various types of cancer, including LCH. BRAF gene located on chromosome 7q34 encodes a cytoplasmic serine-threonine kinase. This mutated BRAF protein constitutively activates the MAPK signaling pathway, which results in increased cell proliferation, apoptosis resistance and tumor progression $[8,9]$.

Specific inhibition of BRAF signaling is effective in blocking proliferation of melanoma cells that have additional genomic abnormalities. Recent identification of cancer-associated mutation BRAF V600E in LCH cases provided molecular evidence of the neoplastic nature of LCH [10]. Initially BRAF was discovered in other types of cancer; additionally, it was found in LCH. Based on such data, it is possible to suggest that melanoma treatment approaches can be used for $\mathrm{LCH}$ treatment taking in consideration the expression of this gene [11]. BRAF mutations are usually found in tumors that have wild-type KRAS and NRAS, KIT, and other driver mutations.

Initially, LCH was considered as a disorder of immune regulation. Activating mutations in the proto-oncogene BRAF-V600E were reported in approximately $50-60 \%$ of cases; mitogen-activated protein kinase (MEK) and extracellular signal-related pathway (ERK) phosphorylation was reported in 100\% of these cases. These data allow to relate $\mathrm{LCH}$ to a dendritic cell neoplasm with a strong inflammatory component. $\mathrm{Cu}$ rrent international LCH trials are focused 
Tab. 1. Primer and probe sequences for analysis of qPCR mutations.

\begin{tabular}{|c|c|c|}
\hline Target & Primer & Sequence \\
\hline \multirow[t]{11}{*}{ KRAS } & common primer $\mathrm{A}$ & GTA CTG GTG GAG TAT TTG ATG TGT ATT AAC C \\
\hline & probe 1 & VIC-CTA CCA CAA GTT TAT ATT CAG TCA TTT TCA-TAMRA \\
\hline & G12V & TAT CGT CAA GGC ACT CTT GCC TAC GCC TA \\
\hline & G12D & TAT CGT CAA GGC ACT CTT GCC TAC GCC TT \\
\hline & G12A & TAT CGT CAA GGC ACT CTT GCC TAC GCC TG \\
\hline & $\mathrm{K} 13 \mathrm{~A}$ & CGT GTA TCG TCA AGG CACTCTTGC CTA CCT \\
\hline & common primer B & CTC ATG AAA ATG GTC AGA GAA ACC TTT ATC \\
\hline & Probe-2 & 6-FAM-CAA GAG TGC CTT GAC GAT ACA GCT A-TAMRA \\
\hline & $\mathrm{G} 12 \mathrm{C}$ & CTG AAT ATA AAC TTG TGG TAG TTG GAG CAT \\
\hline & G12S & CTG AAT ATA AAC TTG TGG TAG TTG GAG CCA \\
\hline & G12R & CTG AAT ATA AAC TTG TGG TAG TTG GAG CCC \\
\hline \multirow[t]{3}{*}{$\beta$-actin } & forward & TCA CCC ACA CTG TGC CCA TCT ACG A \\
\hline & reverse & CAG CGG AAC CGC TCA TTG CCA ATG G \\
\hline & probe & FAM-ATG CCC TCC CCC ATG CCA TCC TGC GT \\
\hline \multirow[t]{4}{*}{$B R A F$} & forward & CTG TTT TCC TTT ACT TAC TAC ACC TCA GAT \\
\hline & reverse (mutant V600E) & CCC ACT CCA TCG AGA TTT CT \\
\hline & reverse (reference) & CAA CTG TTC AAA CTG ATG GG \\
\hline & probe & FAM-CAC AGT AAA AAT AGG TGA T-MGB \\
\hline \multirow[t]{3}{*}{ CYP17 } & forward & CCC TAG AGT TGC CAC AGC \\
\hline & reverse & GGT AAG CAG CAA GAG AGC \\
\hline & probe & VIC-CTG TCT ATC TTG CCT GCC-MGB \\
\hline
\end{tabular}

qPCR - quantitative polymerase chain reaction

on further improving the outcome of patients with high-risk multisystem $\mathrm{LCH}$, by decreasing the reactivation rate, optimizing early salvage regimens and preventing late complications.

Somatic mutations in ARAF and MAP2K1 were recently discovered; these mutations lead to activation of the RAS-RAF-MEK-ERK pathway in the setting of wild-type BRAF. It was also found that the activation of mutation in MAP2K1 is relatively insensitive to MEK inhibitors. This suggests that a more detailed understanding of this pathway in LCH may be necessary for the development of more efficient targeted therapies [12].

\section{Materials and Methods}

We performed the study from February 1, 2009 to March 31, 2017 on biopsy samples received at the Department of Oncohematology of National Cancer Insti- tute, Kiev, Ukraine. Altogether, 8 patients with LCH (6 males and 2 females; median age -25 , age range $-21-55$ ) were included in this study. The diagnosis was based on clinical symptoms and immunohistochemistry results (CD1a+ or CD207+ and S-100+).

The study was approved by the institutional ethics committee review board at the National Cancer Institute of Ukraine.

\section{Quantitative real-time PCR}

All biomaterial was obtained before treatment. Fresh tumor samples for quantitative polymerase chain reaction (qPCR) analysis were stored in 'RNA-later' (Ambion, USA) to stabilize nucleic acids.

DNA was extracted from formalin-fixed, paraffin-embedded tissues after histological control. Genomic DNA from tumor samples was isolated using NucleoSpin Tissue Kit (Macherey-Nagel,
Germany). Primers and probes were specially engineered to determine KRAS tumor genotype (7 mutations located within codons $12(6)$ and $13(1)$ ) by the multiplexed qPCR. Sequences of primers were experimentally selected with Primer Express Software v3.0 (Applied Biosystems, USA) and synthesized by Applied Biosystems, USA. All primer and probe sequences are listed in Tab. 1.

For KRAS mutation analysis, primers and TaqMan probes were used at $20 \mu \mathrm{M}$ and $5 \mu \mathrm{M}$ concentrations, resp. TaqMan Universal PCR Master Mix (Applied Biosystems, USA). Common primer A, mutation-specific primer and probe 1 were used for KRAS G12V, G12D, G12A, K13A mutation analysis, common primer $B$, mutation-specific primer and probe 2 were used for KRAS G12C, G1S, G12R mutation analysis; 5-10 ng of DNA were used to prepare the reaction mix- 
Tab. 2. Response to treatment.

\begin{tabular}{l|l|}
\hline Type of response & $\mathbf{n}$ \\
\hline stable disease & 5 \\
\hline partial response & 1 \\
\hline complete response & 1 \\
\hline relapse/refractory & 1
\end{tabular}

ture in a total volume of $25 \mu \mathrm{l}$. A total of 55 cycles of qPCR $\left(95^{\circ} \mathrm{C}-42\right.$ seconds, $60^{\circ} \mathrm{C}-42 \mathrm{sec}$ and $72^{\circ} \mathrm{C}-52 \mathrm{sec}$ ) were run on 7,300/7,500 Real-Time PCR Systems (Applied Biosystems, USA). This assay uses six primers, two common primers, two TaqMan probes for seven different KRAS mutations. qPCR for an inner control $\beta$-actin was performed for each sample.

For BRAF mutation analysis $\mathrm{qPCR}$ reference PCR was performed in a $25 \mathrm{mkl}$ reaction volume with $1 \mathrm{mkl}$ TaqMan Universal Master Mix (Applied Biosystems, USA), $900 \mathrm{nmol} / \mathrm{L}$ of each BRAF mutation-unspecific primer, $100 \mathrm{nmol} / \mathrm{L}$ of the $B R A F$ probe, $112.5 \mathrm{nmol} / \mathrm{L}$ of each internal control primer, $25 \mathrm{nmol} / \mathrm{L}$ of the internal control probe, and 5-10 ng of DNA of varying concentrations. Allele-specific PCRs were performed according to the same protocol but using a concentration of $450 \mathrm{nmol} / \mathrm{L}$ of allele-specific primer [13]. All real-time PCRs were performed on 7,300/7,500 Real-Time PCR Systems (Applied Biosystems, USA) under the following thermocycling conditions $-95^{\circ} \mathrm{C}$ for $10 \mathrm{~min}$, followed by 50 cycles of $90^{\circ} \mathrm{C}$ for $15 \mathrm{sec}$ and $60^{\circ} \mathrm{C}$ for $1 \mathrm{~min}$. Cycle threshold $(\mathrm{Ct})$ values were recorded for reference PCR and for each allele-specific PCR, and corresponding $C t$ values (ie, allele-specific $\mathrm{Ct}$ minus reference $\mathrm{Ct}$ ) were calculated.

We also studied KRAS minor mutations G13C, Q61R, Q61H, A146T and NRAS mutations G12V, G12D, G12C, G12S, G13V, G13R, Q61K, Q61L, Q61R, Q61HC, Q61HT in tumor samples with TaqMan Mutation Detection Assays (Cat. \#4465804, Applied Biosystems, USA) and a mutation-unspecific region was used as a reference amplicon (Cat. \#4465807, Applied Biosystems, USA).

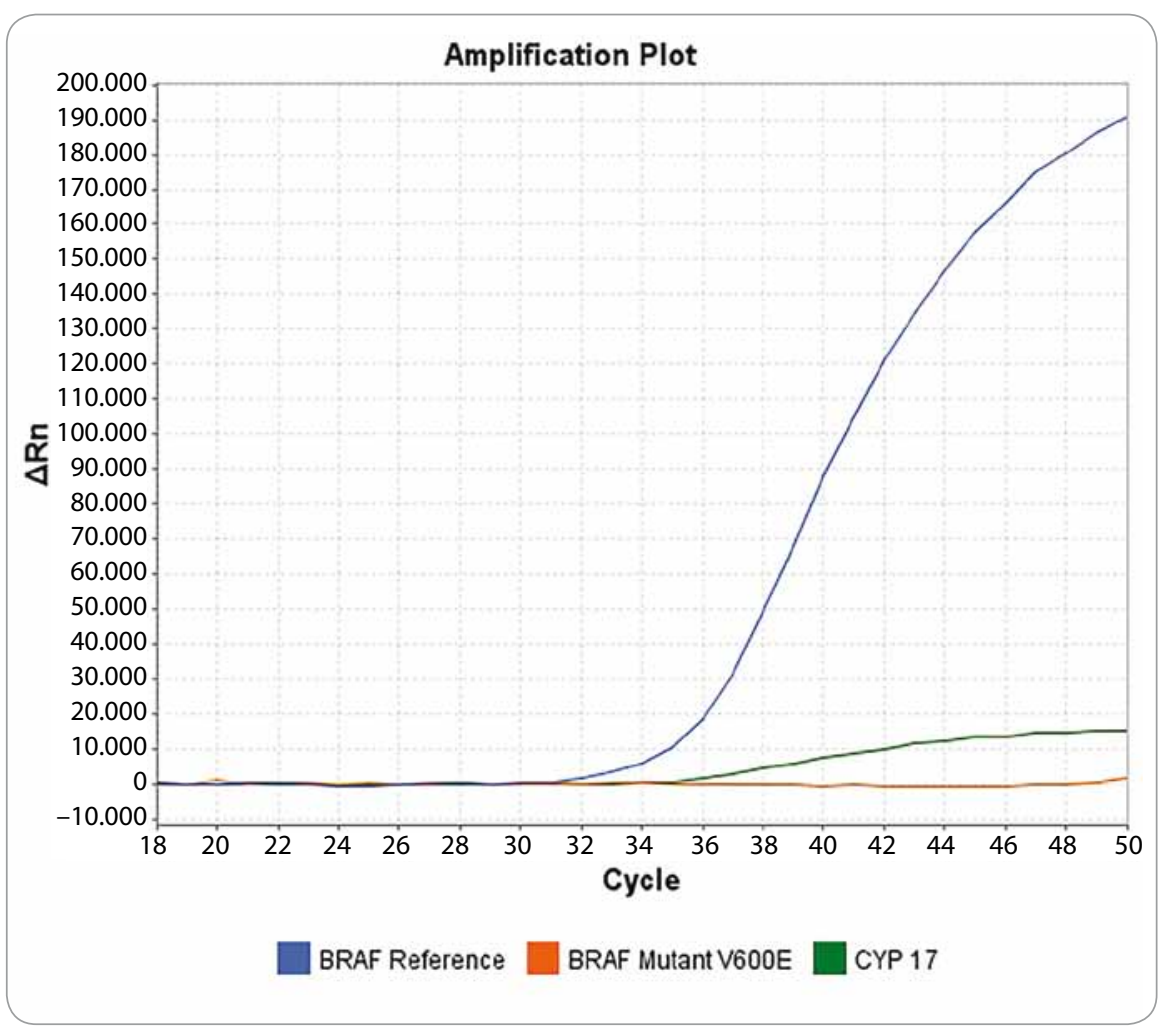

Graph 1. Case 1 SS-LCH with the involvement of bone system, identified by qPCR, no BRAF V600E mutation found.

SS-LCH - single sytem Langerhans cell histocystis, qPCR - quantitative polymerase chain reaction

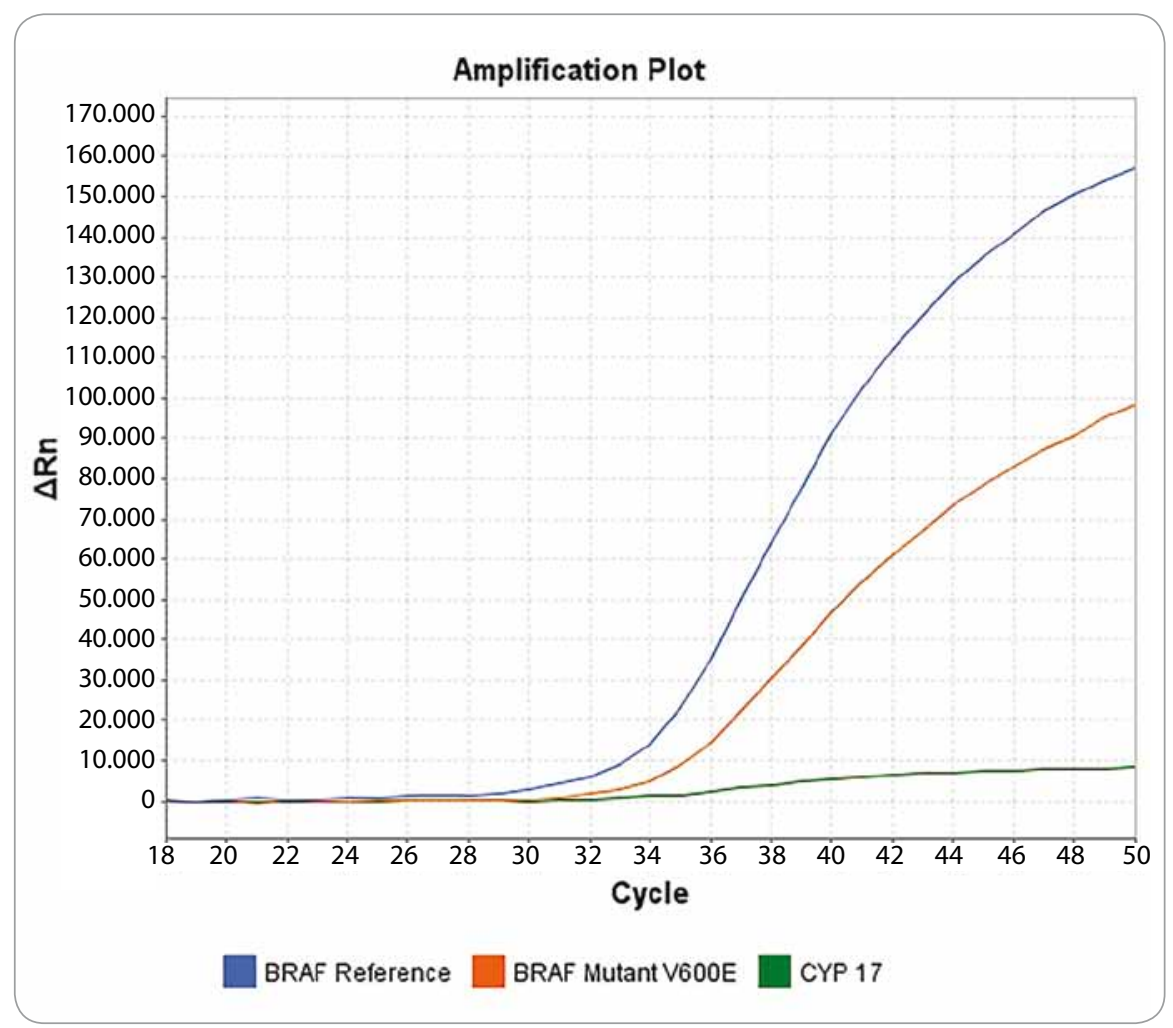

Graph 2. Case 7 MS-LSH with the involvement of "special sites", identified by qPCR, with a BRAF V600E mutation.

MS-LCH-multisystem Langerhans cell histocystis, qPCR - quantitative polymerase chain reaction 


\section{Statistical analysis}

A Spearman correlation coefficient $(r)$ test and Cox test were used to determine the relationship between two continuous measurements. We used Chi-square tests for comparison of the time to relapse (TTR); $p<0.05$ was considered to indicate a statistically significant difference. Survival curves were generated by the Kaplan-Meier method. An overall survival (OS) was calculated from the date of pathological diagnosis to the death or to last follow-up. An event-free survival (EFS) was calculated from the first day of treatment to relapse, progression or death, or to last date of follow-up. All the analyses were carried out using Statistica 10 and MedClac Version 12.6.1.0.

\section{Results}

Single-system disease (SS-LCH) and multi-system LCH (MS-LCH) had 25\% $(2 / 8)$ and $75 \%(6 / 8)$ of patients, resp. $(p<0.05)$.

In two cases, SS-LCH patients had bone involvement and one patient had pulmonary system involvement. The patient with primary LCH of lungs had a long-term history of smoking ( $>10$ years).

Two patients had MS-LCH with the involvement of "risk organs" such as central nervous system and bone marrow, there was only one patient with the involvement of "special sites". In addition, we diagnosed two cases of MS-LCH without the involvement of "risk organs". In our study, the patients older than 32 (50 and 55 years old) had MS-LCH with bone involvement, while patients younger than 24 (22 years old) had their pulmonary system involvement at diagnosis. A total of $62.5 \%$ patients received chemotherapy in combination with radiation therapy, and only $1 / 4$ of patients (37.5\%) received only chemotherapy, $(p<0.05)$. All patients received chemotherapy according to LCH-I protocol, six cycles on average (range $2-8$ ).

The evaluation of response was done after the second or third cycle of chemotherapy. The response to treatment was achieved in $87.5 \%$ (7/8) of cases (Tab. 2.).

The maximum follow-up period in this group of patients was 96.72 months (median 44.92 months). A total of

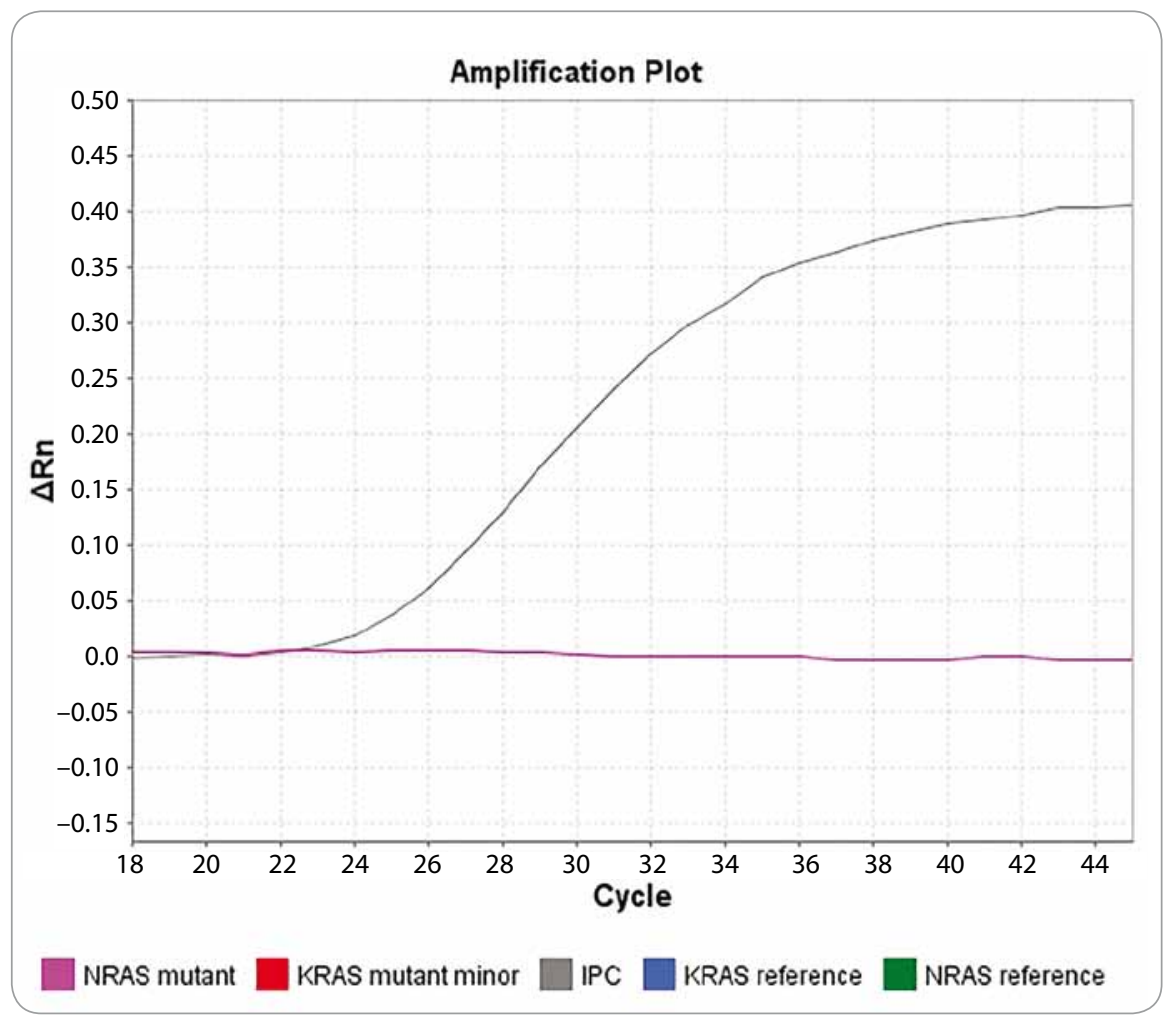

Graph 3. Case $2 \mathrm{MS}-\mathrm{LCH}$, with the involvement of risk organ, identified by qPCR, no NRAS Q61R mutation found.

MS-LCH - multisystem Langerhans cell histocystis, qPCR - quantitative polymerase chain reaction

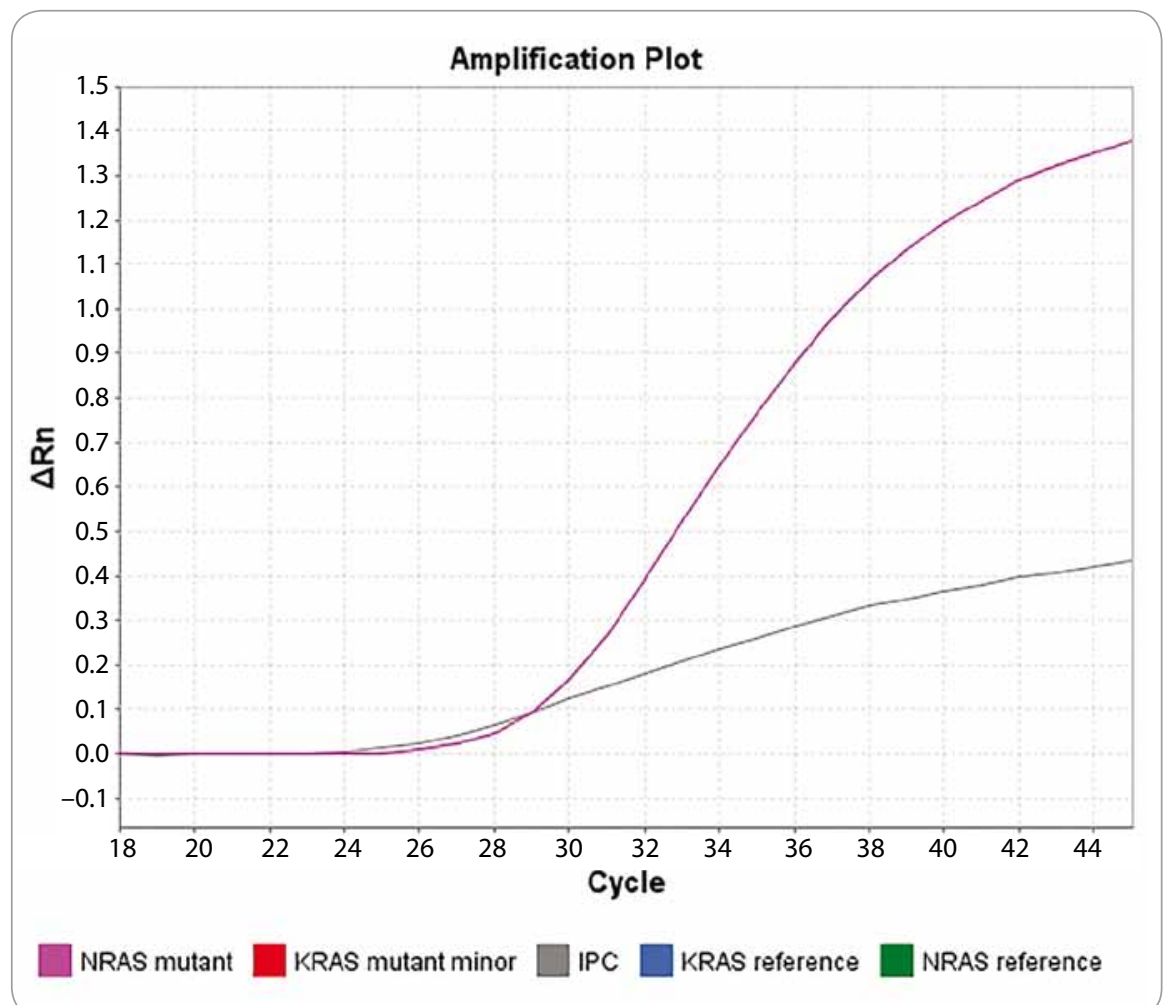

Graph 4. Case 6 MS-LCH, without the involvement of risk organ, identified by qPCR, with a NRAS Q61R mutation.

MS-LCH - multisystem Langerhans cell histocystis, qPCR - quantitative polymerase chain reaction 
Tab. 3. TTR based on disease stratification and BRAF/KRAS/NRAS gene mutations.

\begin{tabular}{|c|c|c|c|c|c|}
\hline LCH stratification & $\begin{array}{c}\text { Patients with } \\
\text { disease progression, } \mathbf{n}\end{array}$ & $\begin{array}{c}\text { BRAF/KRAS/NRAS } \\
\text { gene mutation }\end{array}$ & $\begin{array}{c}\text { TTR } \\
\text { (month) }\end{array}$ & $\begin{array}{l}\text { Relapse } \\
\text { type }\end{array}$ & Death \\
\hline SS-LCH, multifocal > 1 bone & 1 & BRAF V600E & 6 & early & 0 \\
\hline MS-LCH, without the involvement of "risk organ" & 1 & NRAS Q61R & 3 & refractory & 0 \\
\hline MS-LCH, with the involvement of "risk organ" & 1 & NRAS Q61R & 12 & late & 0 \\
\hline MS-LSH, with the involvement of "special sites" & 0 & $B R A F V 600 E$ & 0 & 0 & 0 \\
\hline
\end{tabular}

TTR - time to relaps, LCH - Langerhans cell histiocytosis, MS-LCH - multisystem LCH, SS-LCH - single system LCH

$87.5 \%(7 / 8)$ patients is still being followed up. During the follow-up period, there was one death registered due to the progression in LCH with pulmonary involvement.

There were $2 / 8$ patients with early relapses (in 6 months), 2/8 patients with late relapses and $1 / 8$ patient with refractory disease. In addition, one patient had transformed LCH into Hodgkin lymphoma, which was confirmed by immunohistochemical study.

Three-year EFS was $28.3 \%$. It was impossible to calculate the OS due to the loss to follow-up of one patient. The analysis of data for presence of MAPK/ERK pathway gene mutations did not show any BRAF/KRAS/NRAS mutations in $50 \%$ (4/8) of patients.

We did not find any BRAF, KRAS or NRAS mutations in three patients with late relapses (in 15, 24 and 46 months). Notably, KRAS mutations were not revealed in any LCH samples.

A $B R A F$ c.1799T>A, p. V600E mutation was present only in 2 out of 8 evaluated cases (25\%):

- one patient with early relapse

(in 6 months after the treatment);

- one patient with stable disease (Graph. 1 and 2)

We also identified two patients with NRAS c. $182 \mathrm{~A}>\mathrm{G}$, p. Q61R mutation:

- one patient had LCH transformed to Hodgkin's lymphoma during 12 months after treatment $\mathrm{LCH}$;

- one patient had a refractory disease (Graph 3 and 4.)

Due to a small number of patients in the research group, we decided to intro- duce TTR in months in order to be able to determine the impact of MAPK/EPK pathway mutation on relapse occurrence (Tab. 3).

We also analyzed correlation of disease response to the therapy, OS and EFS with age, sex, LCH stratification, number of cycles, response totherapy, radiation therapy, presence of gene mutations BRAF/KRAS/NRAS.

Unfortunately, due to a small number of patients, we did not identify a statistically significant difference of EFS in patients with or without BRAF V600E gene mutation. However, the comparison of patients with TTR with and without BRAF V600E gene mutation was significant, 13 vs. 28 months, resp.; $p<0.05$.

In addition, TTR was 31.3 vs. 6.41 months in patients with the absence or presence of NRAS mutation, $\mathrm{p}<0.05$. Multivariate analysis confirmed that the presence of NRAS Q61R mutation has a significant association with shorter EFS in LCH patients with $\mathrm{HR}$ of $6.1(95 \% \mathrm{Cl}$ $0.2-12.6 ; p=0.008$ ).

\section{Discussion}

$\mathrm{LCH}$ is a rare disease characterized by clonal proliferation of Langerhans cells [14]. Granuloma-like lesions of LCH have heterogeneous cellular composition. The etiology of Langerhans cell histiocytosis is largely unknown $[15,16]$. Recent studies have suggested that $\mathrm{LCH}$ is related to the clonal neoplastic proliferation of myeloid-derived precursor cells with a high frequency of somatic oncogenic BRAF V600E mutations in 25-60\% of LCH patients [17-20]. Since the follow-up time in our study for some patients was short, the relationship of
BRAF V600E mutation to survival has not been sufficiently analyzed. Smoking is an important factor in primary LCH of lungs [20]; one patient with pulmonary disease had a long-term history of smoking in our study, which may be related to this form of LCH.

Symptoms, such as lytic bone lesions, exophthalmos, polyuria, hepatosplenomegaly, lymphadenopathy, skin rash, and hematological compromise, are most common in patients with LCH [21]. During our study, we most commonly came across such symptoms as lytic bone lesions (62.5\%), lymphadenopathy (50\%), polyuria (25\%).

The overall 5-year survival rate of $\mathrm{LCH}$ patients is $88 \%$ [22]. Patients with unifocal LCH have an excellent prognosis and a high long-term survival rate (99\%), may spontaneously recover or require minimal treatment [22]. In our cohort, one patient died because of pulmonary disease. The other seven patients are still alive, and further follow-up should be performed. There were no spontaneous recovery cases in our study.

The BRAF V600E mutation has been reported in $39-57 \%$ of Langerhans cell histiocytosis cases $[17,19]$. Although the pathophysiology of $\mathrm{LCH}$ remains unclear, activation of the MAPK/ERK signal pathway appears to play a significant role [23]. According to our data, BRAF gene mutation has been registered in only $25 \%$ of patients. The comparison of patients with TTR with and without BRAF V600E gene mutation was significant, 13 vs. 28 months, resp.; $\mathrm{p}<0.05$. Hypothetically, we can assume that the data analysis of a larger patient's cohort would be able to confirm the rela- 
tion of the response to treatment with or without the expression of BRAF V600E gene mutation. BRAF gene can be used as a prognostic marker for the assessment of patient's response to treatment, receiving a standard chemotherapy for $\mathrm{LCH}$ as well as for patients participating in clinical trials.

The fact that some of $\mathrm{LCH}$ patients do not carry BRAF gene mutations prompts a possibility of other mutations that are partially or entirely related to ERK pathway and require further research. We did not find any BRAF, KRAS or NRAS mutations in three patients with late relapses.

Approximately $30 \%$ of $\mathrm{LCH}$ tumors have MAP2K1 mutations. Somatic MAP2K1 mutations have been identified in approximately $50 \%$ of $B R A F-$ LCH samples [24]. In our study, there were also two BRAF patients who had a NRASQ61K/R somatic mutation. In addition, there are studies showing that the presence of concurrent BRAF V600E or NRASQ61K/R mutations was strongly associated with patient outcome [25]. Multivariate analysis in our cohort showed that presence $N R A S Q 61 K / R$ gene mutation has a significant association with poor clinical outcome in patients with $\mathrm{LCH}$. Moreover, somatic mutations affecting other $B R A F$ residues, as well as the $A R A F$ gene, have recently been described [18,23].

The determination of the genetic mutation in $\mathrm{LCH}$ lesions has important implications for specific treatment. BRAF inhibitors, such as vemurafenib, have been successfully used to treat LCH patients with the V600E mutation [26]. The test for this mutation may play an important role for an individualized treatment. Additionally, a recent report on the successful use of BRAF protein inhibitor on refractory hairy cell leukemia [27] emphasized that LCH can potentially be treated with targeted therapy.

\section{Conclusion}

In summary, the presence or absence of one of MAPK/EPK pathway mutations, such as BRAF, NRAS or KRAS in a tumor, does not confirm or rule out a diagnosis of $\mathrm{LCH}$. The results of these tests should be correlated with clinical findings and histopathologic features. Unfortunately, we did not find a strong significant impact of BRAFV600E gene mutation on clinical outcomes in patients with LCH in our study. However, our results provide evidence that NRASQ61K/R gene mutation can predict clinical outcome in patients with LCH and seem to be promising for the future studies.

\section{References}

1. Lee JS, Ko GH, Kim HC et al. Langerhans cell sarcoma arising from Langerhans cell histiocytosis: a case report. J Korean Med Sci 2006; 21(3): 577-580. doi: 10.3346/jkms.2006.21.3.577.

2. Arico M, Girschikofsky M, Généreau T et al. Langerhans cell histiocytosis in adults. report from the internationa registry of the histiocyte society. Eur J Cancer 2003; 39(16): 2341-2348

3. Kriachok IA, Skrypets TV, Novosad Ol et al. Therapeutic approaches to the treatment of adult patients with Langerhan cell histiocytosis. J Clin Oncol Ukraine 2016; 1 (21): 58-62.

4. Broadbent V, Pritchard J, Davies EG et al. Spontaneous remission of multi-system histiocytosis X. Lancet 1984; 1(8371): 253-254.

5. Coury F, Annels N, Rivollier A et al. Langerhans cell histiocytosis reveals a new IL-17A-dependent pathway of dendritic cell fusion. Nat Med 2008; 14(1): 81-87. doi 10.1038/nm1694.

6. Willman $\mathrm{CL}$, Busque $\mathrm{L}$, Griffith BB et al. Langerhan's-cell histiocytosis (histiocytosis $\mathrm{X}$ ): a clonal proliferative disease. N Engl J Med 1994; 331(3): 154-160. doi: 10.1056/NEJM199407213310303.

7. da Costa CE, Szuhai K, van Eijk R et al. No genomic aberrations in Langerhans cell histiocytosis as assessed by diverse molecular technologies. Genes Chromosome Cancer 2009; 48(3): 239-249. doi: 10.1002/gcc.20634. 8. Cantwell-Dorris ER, O'Leary JJ, Sheils OM. BRAFV600E: implications for carcinogenesis and molecular therapy. Mol Cancer Ther 2011; 10(3): 385-394. doi: 10.1158/15357163.MCT-10-0799.

9. Davies H, Bignell GR, Cox C et al. Mutations of the BRA gene in human cancer. Nature 2002; 417(6892): 949-954. doi: 10.1038/nature00766

10. Novosad O, Kryachok I, Khranovska $\mathrm{N}$ et al. The MAPK/ERK pathway activation in patients with Langerhans Cell Histiocytosis. abstr. BMS-P-3. In: 18th Meeting of the European Association for Haematopathology - EAHP. Basel, 3.-8. September 2016.

11. Badalian-Very G, Vergilio JA, Degar BA. Recurrent BRAF mutations in Langerhans cell histiocytosis. Blood 2010;
116(11): 1919-1923. doi: 10.1182/blood-2010-04-279 083.

12. Abla O, Weitzman S. Treatment of Langerhans cell histiocytosis: role of BRAF/MAPK inhibition. Hematology Am Soc Hematol Educ Program 2015; 2015: 565-570. doi: 10.1182/asheducation-2015.1.565.

13. Lang AL, Drexel H, Geller-Rhomberg S et al. Optimized allele-specific real-time PCR assays for the detection of common mutations in KRAS and BRAF. J Mol Diagn 2011; 13(1): 23-28. doi: 10.1016/j.jmoldx.2010.11.007.

14. Allen CE, Li L, Peters TL et al. Cell-specific gene expression in Langerhans cell histiocytosis lesions reveals a distinct profile compared with epidermal Langerhans cells. J Immunol 2010; 184(8): 4557-4567. doi: 10.4049/jimmunol.0902336.

15. Jaffe R, Weiss LM, Facchetti F. Tumours derived from Langerhans cells. In: Swerdlow SH, Campo E, Harris NL (eds). WHO classification of tumours the haematopoietic and lymphoid tissues. Lyon: IARC Press; 2008: 358-360. 16. Paulus W, Perry A. Histiocytic tumours. In: Louis DN, Ohgaki $\mathrm{H}$, Wiestler OD (eds). WHO classification of tumours the central nervous system. Lyon: IARC Press; 2007: 193-196. 17. Badalian-Very G, Vergilio JA, Degar BA et al. Recurrent BRAF mutations in Langerhans cell histiocytosis. Blood 2010; 116(11): 1919-1923. doi: 10.1182/blood-2010-04-279083. 18. Satoh T, Smith A, Sarde A et al. B-RAF mutant alleles associated with Langerhans cell histiocytosis, a granulomatous pediatric disease. PLoS One 2012; 7(4): e33891. doi: 10.1371/journal.pone.0033891.

19. Sahm F, Capper D, Preusser M et al. BRAFV600E mutant protein is expressed in cells of variable maturation in Langerhans cell histiocytosis. Blood 2012; 120(12): e28-e34. doi: 10.1182/blood-2012-06-429597.

20. Roden AC, Hu X, Kip S et al. BRAF V600E expression in Langerhans cell histiocytosis: clinical and immunohistochemical study on 25 pulmonary and 54 extrapulmonary cases. Am J Surg Pathol 2014; 38(4): 548-551. doi: 10.1097/PAS.0000000000000129

21. Badalian-Very G, Vergilio JA, Fleming M et al. Pathogenesis of Langerhans cell histiocytosis. Annu Rev Pathol 2013; 8: 1-20. doi: 10.1146/annurev-pathol-020712163959.

22. Grana N. Langerhans cell histiocytosis. Cancer Control 2014; 21(4): 328-334. doi: 10.1177/107327481402100409. 23. Nelson DS, van Halteren A, Quispel WT et al. MAP2K1 and MAP3K1 mutations in Langerhans cell histiocytosis. Genes Chromosomes Cancer 2015; 54(6): 361368. doi: 10.1002/gcc.22247.

24. Brown, NA, Furtado LV, Betz BL et al. High prevalence of somatic MAP2K1 mutations in BRAF V600E-negative Langerhans cell histiocytosis. Blood 2014; 124(10): 1655 1658. doi: 10.1182/blood-2014-05-577361

25. Mourah S, How-Kit A, Meignin V et al. Recurrent NRAS mutations in pulmonary Langerhans cell histiocytosis. Eur Respir J 2016; 47(6): 1785-1796. doi: 10.1183/13993003.01677-2015.

26. Haroche J, Cohen-Aubart F, Emile JF et al. Dramatic efficacy of vemurafenib in both multisystemic and refractory Erdheim-Chester disease and Langerhans cell histiocytosis harboring the BRAF V600E mutation. Blood 2013; 121(9): 1495-1500. doi: 10.1182/blood-2012-07-446286. 27. Dietrich $S$, Glimm H, Andrulis M et al. BRAF inhibition in refractory hairy-cell leukemia. N Engl J Med 2012; 366(21): 2038-2040. doi: 10.1056/NEJMc1202124. 